\title{
Asesmen Formatif Perkembangan Bahasa Anak
}

\author{
Irena Agatha Simanjuntak ${ }^{1}$, Sa'dun Akbar ${ }^{2}$, Alif Mudiono ${ }^{2}$ \\ ${ }^{1}$ Pendidikan Anak Usia Dini-Universitas Negeri Malang \\ ${ }^{2}$ Keguruan Sekolah Dasar dan Prasekolah-Universitas Negeri Malang
}

\section{INFO ARTIKEL}

\section{Riwayat Artikel:}

Diterima: 31-07-2019

Disetujui: 21-08-2019

\section{Kata kunci: \\ formative assessment; developmental assessment; child language development; asesmen formatif; asesmen perkembangan; perkembangan bahasa anak}

\begin{abstract}
ABSTRAK
Abstract: Early childhood education has principles that are stick with playing by learning. So the assessment is done specifically for specificity, in contrast to the lessons for elementary and secondary schools, which need to be carried out carefully and carefully. In application applications, the general term is replaced by the assessment term in PAUD. The method that used in this study is descriptive qualitative. The results of this study indicate the fact that the most commonly used formative assessment forms are interviews, observations, checklists, and portfolios. The four information techniques were chosen because they were effective, in accordance with the needs of the child and the teacher, described of children's development ability clearly and precisely.

Abstrak: Pendidikan anak usia dini memiliki prinsip yang lekat dengan bermain sambil belajar sehingga penilaian yang dilakukan harus memiliki kekhususan tersendiri, berbeda dengan penilaian untuk sekolah dasar dan menengah yang perlu dilaksanakan secara cermat dan hati-hati. Pada tataran aplikasi, istilah penilaian umumnya digantikan dengan istilah asesmen di dunia PAUD. Metode yang digunakan pada penelitian ini adalah deskriptif kualitatif. Hasil penelitian ini menunjukkan bahwa bentuk asesmen formatif yang paling sering digunakan adalah wawancara, observasi, checklist, dan portofolio. Keempat teknik informasi tersebut terpilih karena efektif sesuai kebutuhan anak dan guru, serta mendeskripsikan perkembangan kemampuan anak secara jelas dan tepat
\end{abstract}

\author{
Alamat Korespondensi: \\ Irena Agatha Simanjuntak \\ Pendidikan Anak Usia Dini \\ Universitas Negeri Malang \\ Jalan Semarang 5 Malang \\ E-mail: realirena@gmail.com
}

Masa usia dini sering disebut dengan istilah "golden age” atau masa emas. Pada masa ini, hampir seluruh potensi anak mengalami masa peka untuk tumbuh dan berkembang secara cepat dan hebat. Dalam konteks pendidikan anak usia dini, pendidikan mengandung makna sebagai upaya menstimulasi anak secara konsisten. PAUD semakin diakui sebagai bagian integral dari upaya untuk memastikan bahwa semua anak masuk sekolah siap belajar dan sebagai cara untuk membantu menutup kesenjangan prestasi yang ada pada saat anak memasuki sekolah dasar. Hal ini sesuai dengan definisi pendidikan anak usia dini berdasarkan UU no. 20 Tahun 2003 yang menyatakan bahwa PAUD adalah suatu upaya pembinaan yang ditujukan kepada anak sejak lahir sampai usia enam tahun yang dilakukan melalui pemberian rangsangan pendidikan untuk membantu pertumbuhan dan perkembangan jasmani dan rohani agar anak memiliki kesiapan dalam memasuki pendidikan lebih lanjut. Sehingga berbagai aktivitas awal yang dipelajari anak sangat berkaitan dengan kompetensi dan pengalaman mereka yang bersifat direksional dan berbalasan. Pengalamanpengalaman anak tersebut mesti dibangun dan memperoleh stimulasi yang tepat baik dari orangtua, guru, lingkungan, orang dewasa sehingga akan menguntungkan anak. Di sinilah PAUD menjadi suatu proses yang sangat penting dan strategis untuk dilakukan.

Salah satu faktor pendukung keberhasilan penyelenggaraan PAUD adalah pendidik yang profesional. Salah satu kompetensi yang perlu dikuasai pendidik profesional adalah melaksanakan penilaian. Pernyataan tersebut didukung oleh pendapat (Novianti, Puspitasari, \& Chairilsyah, 2013) bahwa salah satu kompetensi pedagogik guru PAUD adalah menyelenggarakan penilaian dan evaluasi proses dan hasil belajar, serta dapat memanfaatkan hasil penilaian dan evaluasi untuk kepentingan pembelajaran. Fungsi penilaian bagi guru, agar dapat dimanfaatkan untuk umpan balik dalam memperbaiki kegiatan pembelajaran, sebagai bahan pertimbangan untuk melakukan kegiatan bimbingan agar tumbuh kembang anak baik secara fisik dan psikis optimal, serta bahan pertimbangan untuk mengelompokkan anak pada kegiatan pembelajaran yang sesuai dengan minat dan kebutuhannya. Penilaian dalam penyelenggaran sebuah pendidikan sangat diperlukan karena dapat menjadi alat bantu bagi pendidik untuk meningkatkan mutu pendidikan di dalam kelas.

Menurut (Bredekamp \& Rosegrant, 1992) penilaian adalah proses mengamati, mencatat, dan mendokumentasikan pekerjaan yang dilakukan anak-anak dan bagaimana mereka melakukannya, sebagai dasar untuk berbagai keputusan pendidikan yang memengaruhi anak. Penilaian adalah bagian integral dari kurikulum dan pengajaran. Dalam program anak usia dini, penilaian memiliki beberapa tujuan berbeda; (1) untuk merencanakan instruksi untuk individu dan kelompok dan untuk 
berkomunikasi dengan orangtua, (2) untuk mengidentifikasi anak-anak yang mungkin membutuhkan layanan atau intervensi khusus, dan (3) untuk mengevaluasi seberapa baik program ini mencapai tujuannya, dan (3) untuk mengevaluasi seberapa baik program bertemu dengan tujuan."

Berdasarkan pernyataan di atas, dapat disimpulkan bahwa penilaian memberikan informasi yang bermanfaat bagi guru untuk berhasil memenuhi tanggungjawab mereka, seperti untuk mendukung pembelajaran dan perkembangan anak-anak, merencanakan individu dan kelompok, dan berkomunikasi dengan orangtua. Asesmen atau biasa disebut penilaian, yang dilakukan pada anak yang duduk di PAUD tentunya berbeda dengan asesmen yang diperuntukkan bagi individu yang dewasa. Penilaian yang dipilih untuk menginformasikan instruksi untuk anak kecil harus digunakan dalam rutinitas sehari-hari, kegiatan, dan tempat dan memasukkan informasi dari berbagai sumber. Bukti yang menginformasikan instruksi harus dikumpulkan dari waktu ke waktu. Cuplikan tunggal tidak memberikan gambaran lengkap dan akurat tentang kemampuan anak

Penilaian dikenal karena efek pembatalannya pada pembelajaran. Menurut (Sarivan, 2011) studi menunjukkan dampak negatif dari kebijakan penilaian, seleksi, metodologi pada guru dan siswa mereka. Ketidakcukupan paling umum yang ditimbulkan oleh pembatalan asesmen akibat kebingungan antara sarana dan tujuan. Maka dari itu, asesmen harus dapat dipercaya dan valid; selaras dengan standar, ekspektasi sesuai usia, dan kurikulum; memeriksa bidang-bidang utama pembelajaran dan pengembangan.

Sistem penilaian yang komprehensif membahas beberapa tujuan masing-masing dengan implikasi untuk penggunaan data. Tujuan ini termasuk (1) penilaian yang digunakan untuk mendukung pembelajaran dan instruksi, (2) penilaian yang digunakan untuk mengidentifikasi anak-anak yang mungkin membutuhkan layanan tambahan, (3) penilaian yang digunakan untuk evaluasi program dan untuk memantau tren, dan (4) penilaian yang digunakan untuk akuntabilitas berisiko tinggi. Penilaian ini dapat lebih lanjut diklasifikasikan menjadi tiga tingkatan, sumatif, interim, dan formatif. Asesmen formatif adalah proses yang menyediakan hubungan kritis antara standar, kurikulum, dan pengajaran. Menurut (Carr, 2001) asesmen dapat dibilang alat kebijakan yang paling kuat dalam Pendidikan, tidak hanya dapat digunakan untuk mengidentifikasi kekuatan dan kelemahan individu, institusi, dan bahkan seluruh sistem pendidikan, tetapi juga dapat digunakan sebagai sumber pengaruh yang kuat untuk membawa perubahan.

Asesmen formatif adalah salah satu komponen dari sistem penilaian yang komprehensif. Komprehensif sistem penilaian didefinisikan sebagai, "sistem yang terkoordinasi dan komprehensif dari berbagai penilaian masing-masing yang valid dan dapat diandalkan untuk tujuan yang ditentukan dan untuk populasi yang akan menjadi digunakan - yang mengatur informasi tentang proses dan konteks pembelajaran anak-anak dan pengembangan untuk membantu pendidik anak usia dini membuat instruksi dan program yang diinformasikan keputusan. Suatu sistem penilaian yang komprehensif mencakup, paling tidak, langkah-langkah penyaringan, formatif penilaian, ukuran kualitas lingkungan, dan ukuran kualitas anak dewasa interaksi. Menurut (Ayers, 2014) "Formative assessment is much more than repeated assessment measures over time. Formative assessment is a process, which includes a feedback loop to assist children in closing the gap between current status and desired outcomes, milestones, or goals" yang dapat diartikan bahwa Penilaian formatif jauh lebih dari sekadar ukuran penilaian yang diulang dari waktu ke waktu. Penilaian formatif adalah proses, yang mencakup putaran umpan balik untuk membantu anak menutup kesenjangan antara realita dengan hasil yang diinginkan, perkembangan penting, atau tujuan pembelajaran.

Asesmen formatif adalah proses yang digunakan guru untuk mengumpulkan dan menggunakan informasi penilaian instruksi untuk kebutuhan individu anak-anak Mengumpulkan informasi dari berbagai sumber dan menganalisisnya sesuai dengan kebutuhan pembelajaran individu anak-anak dapat mendukung mengajar di mana semua anak terus belajar dan berkembang. Idealnya, pendidik anak usia dini menanamkan penilaian formatif dalam instruksi dengan bekerja langsung dengan anak-anak untuk mengumpulkan informasi tentang apa yang anak-anak ketahui dan dapat lakukan, bagaimana mereka memproses informasi dan memecahkan masalah, dan bagaimana mereka berinteraksi dengan anak-anak dan orang dewasa lainnya. Penilaian formatif mungkin termasuk instrumen penilaian yang informal, tetapi sistematis, diperiksa dan diterbitkan, ditanam di rumah instrumen penilaian, dan prosedur pengumpulan data yang digunakan oleh guru di ruang kelas.

Salah satu aspek perkembangan yang harus dituntaskan pada pendidikan anak usia dini adalah perkembangan bahasa. Menurut (Santrock, 2009), bahasa adalah suatu bentuk komunikasi baik secara lisan, tertulis, maupun tanda yang didasarkan pada sebuah sistem simbol-simbol. Perkembangan kemampuan bahasa anak usia dini dan usia taman kanak-kanak, tidak lepas dari aspek kemampuan kognitif yang dimilikinya. Bahasa terdiri dari kata-kata yang digunakan oleh suatu komunitas dan aturan untuk mewariskan dan menggabungkannya. Kemampuan anak seperti ini, dikatakan oleh Treiman \& Brodeick, 1998 (Clark \& Kirk, 2000) “...A young preschool child typically recognizes and labels the initial letter of his own first name before recognizing and labeling other letters”. Demikian juga halnya dengan yang dikatakan (Bodrova \& Leong, 1996) bahwa “...children to put this into simpler language, children become capable of thinking as they talk”. Dapat disimpulkan bahwa bahasa adalah keterampilan khusus yang sifatnya kompleks dan naluriah, berkembang dalam diri anak berupa bentuk komunikasi, baik itu lisan, tertulis maupun isyarat. 


\section{METODE}

Penelitian ini menggunakan rancangan penelitian deskriptif kualitatif. Penelitian deskriptif kualitatif digunakan untuk menggambarkan suatu keadaan obyek. Menurut (Sukmadinata, 2013) penelitian deskriptif tidak bermaksud untuk menguji hipotesis atau teori tertentu, tetapi hanya menggambarkan tentang suatu variabel, gejala atau keadaan. Rancangan deskriptif kualitatif ini bertujuan untuk menggambarkan pelaksanaan asesmen formatif pada aspek bahasa anak kelompok B di TK Kartika Kota Batu. Peneliti hadir di lokasi penelitian dengan tidak memberikan perlakuan apapun terhadap subyek penelitian, peneliti hadir untuk mencari informasi mendalam tentang pembiasaan membaca yang dilaksanakan tanpa mengubah, menambah atau mengurangi kegiatan yang ada di lokasi penelitian. Sumber data yang digunakan dalam penelitian ini adalah kata-kata, tindakan, sumber tertulis dan dokumen. Pengumpulan data dalam penelitian ini menggunakan tiga jenis teknik, meliputi (1) observasi partisipan; (2) wawancara mendalam; (3) studi dokumentasi. Analisis data yang dilakukan peneliti bersamaan dengan proses pengumpulan data.

\section{HASIL}

Penelitian ini mengambil lokasi TK Kartika Batu yang beralamatkan di Jalan Imam Bonjol IV/50 di kelurahan Sisir, kecamatan Batu. Lokasi penelitian terletak di daerah jalan protokol, namun tetap kondusif karena jauh dari kawasan industri. Adapun subjek penelitian dalam penelitian ini terdiri dari satu kepala sekolah (merangkap guru), tiga guru kelas, dan dua kelas kelompok B. Peneliti mengamati keseharian guru maupun murid ketika pelaksanaan pembelajaran berlangsung. Berikut daftar pendidikan terakhir guru (tabel 1).

Selain itu, peneliti melakukan observasi awal untuk mengamati jenis-jenis asesmen yang digunakan guru dalam keseharian pembelajaran dapat dilihat pada tabel 2. Berdasarkan temuan peneliti, peneliti menyimpulkan bahwa jenis asesmen formatif yang paling sering digunakan guru adalah wawancara, observasi, checklist, dan portofolio. Hasil wawancara yang dilakukan peneliti memberikan gambaran bahwa asesmen formatif terutama pada aspek perkembangan bahasa lebih tepat menggunakan keempat teknik asesmen tersebut.

Tabel 1. Daftar Pendidikan Terakhir Guru

\begin{tabular}{cl}
\hline Inisial & \multicolumn{1}{c}{ Pendidikan } \\
\hline $\mathrm{Z}$ & S1 PAUD \\
$\mathrm{Y}$ & S1 PAUD \\
$\mathrm{R}$ & S1 Bahasa Indonesia \\
$\mathrm{N}$ & S1 PAUD \\
\hline
\end{tabular}

Tabel 2. Daftar Asesmen yang digunakan Guru

\begin{tabular}{lcccc}
\hline Jenis Asesmen & Guru & Guru & Guru & Guru \\
& $\mathbf{Z}$ & Y & R & N \\
\hline Wawancara & $\sqrt{ }$ & $\sqrt{ }$ & $\sqrt{ }$ & $\sqrt{ }$ \\
Observasi & $\sqrt{ }$ & $\sqrt{ }$ & $\sqrt{ }$ & \\
Catatan & & & $\sqrt{ }$ & \\
Anekdot & & $\sqrt{ }$ & $\sqrt{ }$ & $\sqrt{ }$ \\
Checklist & & $\sqrt{ }$ & $\sqrt{ }$ & $\sqrt{ }$ \\
Portofolio & $\sqrt{ }$ & $\sqrt{ }$ & & $\sqrt{ }$ \\
Unjuk Kerja & & $\sqrt{ }$ & & \\
Hasil Karya & & & & \\
\hline
\end{tabular}

\section{PEMBAHASAN}

Pelaksanaan asesmen di TK Kartika beragam, guru memiliki format yang didesain khusus dan terintegrasi dengan RPPH yang telah dibuat guru. Setiap guru memiliki tanggungjawab tugas sebagai guru sentra. TK Kartika sendiri memiliki empat sentra, meliputi sentra persiapan, sentra kreativitas, sentra bahan alam, dan sentra balok. Asesmen formatif tersebut digunakan untuk mendokumentasikan hasil-hasil pencapaian maupun asesmen yang diperlukan guru untuk memperoleh informasi selengkaplengkapnya terkait individu anak. Menurut (Hus \& Matjašič, 2017) dalam melakukan asesmen, guru harus menciptakan situasi belajar dimana anak menunjukkan keterampilan mereka dengan pemberian tugas yang realistis dan bermakna bagi anak. Pernyataan ini sesuai dengan kondisi lapangan karena asesmen tidak dapat dilakukan apabila anak belum memahami instruksi tentang pengalaman pembelajaran yang ia terima. Guru memiliki tugas untuk mengasesmen sejauh mana kemampuan anak telah berkembang dan sejauh mana tujuan pembelajaran yang telah tercapai. 
Pelaksanaan asesmen dilakukan berkala selama pembelajaran berlangsung. Menurut Bergeson (Irayana, 2017) ada lima tujuan utama dalam asesmen pendidikan, yaitu screening menentukan kelayakan, perencanaan program, monitoring kemajuan anak, dan evaluasi sebuah program. Pendidik memerlukan strategi untuk melakukan asesmen kebutuhan dan kemampuan individual anak usia dini, sehingga pendidikan anak usia dini yang komprehensif dapat terlaksana dengan baik. Asesmen formatif bahasa dipilih karena aspek tersebut tidak dapat dipisahkan dengan aspek lainnya. Aspek bahasa akan selalu bersinggungan dengan aspek lainnya, karena perkembangan maupun kemampuan bahasa anak berkembang seiring dengan berkembangnya aspek-aspek lainnya. Adapun langkah-langkah asesmen menurut (Setiawan, Sa'dijah, Akbar, 2017) asesmen dilakukan guru dengan merumuskan kisi-kisi asesmen yang disesuaikan dengan kompetensi dalam kurikulum, aspek yang didata, dan tujuan pembelajaran yang telah dirumuskan, dan membandingkannya dengan keadaan dan kemampuan anak dalam pembelajaran. Data hasil asesmen akan ditindak lanjuti dengan pemberian keputusan atau penilaian sesuai dengan kriteria yang telah ditetapkan. Dapat disimpulkan, asesmen melibatkan pengamatan berkala dan beruntun terhadap anak dalam berbagai keadaan yang mewakili perilaku anak dalam program dari waktu ke waktu. Hal itu bergantung pada prosedur yang mencerminkan kehidupan kelas yang berkelanjutan dan kegiatan khas anak-anak.

Menurut Frisby dan Wiggins (Pierce, 2002) sebagian besar penilaian yang digunakan di kelas dikembangkan oleh guru dan penilaian pekerjaan siswa ini lebih berpengaruh pada keputusan instruksional daripada tes yang diamanatkan negara (Frisby, 2001; Wiggins, 1998). Hal ini menunjukkan bahwa tidak ada format khusus atau teknik yang wajib digunakan guru, karena semuanya kembali kepada kebutuhan sekolah dan anak. Istilah "asesmen" sering digunakan untuk mengomunikasikan niat untuk membangun gambaran yang lebih kaya tentang cara orang berpikir, belajar, dan bekerja. Mereka sering dilakukan dalam periode waktu yang lebih lama daripada izin tes kelompok. Tes terstandarisasi berfokus pada perbedaan individu, menjawab pertanyaan "Bagaimana individu ini dibandingkan dengan semua orang lain dalam populasi referensi?" Asesmen mencerminkan minat teori kognitif modern dalam proses belajar dan pengetahuan pada individu tertentu.

\section{Wawancara}

Wawancara adalah teknik untuk mengumpulkan data yang dapat dilakukan guru guna menggali informasi baik itu tentang pengetahuan ataupun penalaran anak tentang sesuatu hal dengan cara melakukan percakapan langsung dengan anak maupun orangtuanya, (Dunphy, 2010). Wawancara klinis, sebagai metode, telah dikembangkan selama bertahun-tahun sejak pertama kali digunakan oleh (Piaget \& Inhelder, 1997). Sangat menarik ketika metode penyelidikan tradisional, seperti observasi, tidak memadai untuk mengungkap pemikiran anak-anak. Selama wawancara, pendidik 'bertindak sebagai dokter dalam menilai bagaimana menanggapi anak-anak yang berbeda dengan menjadi peka terhadap nuansa kebutuhan individu.

Wawancara menggabungkan beberapa metode: observasi, tes, eksperimen, dan "berpikir keras-keras." Pewawancara mengamati perilaku anak dan mendengarkan verbalisasi anak; menyajikan "benda uji" — masalah dari berbagai jenis, seringkali melibatkan benda konkret; percobaan dengan berbagai pertanyaan atau tugas untuk menguji hipotesis; dan meminta anak untuk berpikir keras, untuk mengungkapkan proses berpikir sejelas mungkin. Pernyataan ini dapat diartikan bahwa melalui wawancara, guru dapat menggali lebih jauh kondisi objektif anak dan mendapatkan informasi mengenai pengetahuan anak terhadap sesuatu hal. Seiring berkembangnya wawancara, tugas dan pertanyaan sebagian ditentukan oleh respons anak. Tugas bervariasi dan dimodifikasi, menjadi lebih spesifik untuk fokus pada aspek pemikiran tertentu, dan lebih sulit untuk menguji batas pemahaman. Dalam wawancara klinis, perilaku pemeriksa sedikit banyak bergantung pada anak; dalam pengujian standar, perilaku anak selalu bergantung pada pertanyaan pemeriksa.

\section{Observasi}

Asesmen ini menyediakan sarana untuk mengamati secara sistematis kegiatan anak-anak dalam kesempatan yang terkandung untuk interaksi antara guru dan anak terjadi, dan, kedua, interaksi ini harus terjadi dari waktu ke waktu, bukan pada satu kesempatan. Pandangan ini tidak berpendapat bahwa seseorang dapat mengumpulkan semua anak-anak TK di suatu komunitas pada hari tertentu dan menguji mereka untuk menentukan apa yang mereka ketahui dan dapat lakukan. Sebaliknya, ini menunjukkan bahwa pembelajaran hanya dapat dinilai dari waktu ke waktu dan dalam konteks. Observasi merupakan pengamatan yang dilakukan guru secara langsung dan alamiah untuk mendapatkan data atau informasi tentang perkembangan dan permasalahan anak dalam berbagai situasi dan kegiatan yang dilakukan. Menurut (Dunphy, 2010) observasi telah diakui sejak lama sebagai kunci untuk mengungkap pembelajaran anak-anak, makna tindakan mereka, tanda anak, dan kata-kata mereka.

Pendidik yang memiliki hubungan pribadi yang lekat dengan anak-anak adalah orang-orang yang paling baik untuk mengamati pembelajaran mereka. Mengenali dan berusaha memahami sinyal emosional anak-anak sangat penting, seperti interpretasi pesan anak-anak yang diungkapkan melalui bahasa tubuh mereka dan perilaku non-verbal dan verbal. Hal yang paling penting dalam melakukan penilaian terhadap anak adalah melakukan pengamatan langsung terhadap sikap, pengetahuan, dan keterampilan anak. Observasi dapat dilakukan dengan cara mengamati berbagai perilaku atau perubahan yang ditunjukkan anak selama kurun waktu tertentu. Agar observasi dapat terarah, guru dapat menggunakan instrumen observasi dengan tetap mengacu pada indikator pencapaian perkembangan anak. 


\section{Checklist}

Checklist merupakan alat perekam hasil observasi terhadap aspek perkembangan anak usia dini. Checklist dan skala penilaian digunakan untuk membuat penilaian tentang perilaku anak-anak. Keduanya harus digunakan dalam pengaturan yang berbeda untuk menentukan pola dalam perilaku. Checklist tersebut memuat indikator perkembangan untuk setiap Kompetensi Dasar anak usia dini. Guru menggunakan proses penilaian formatif untuk memandu instruksi harian dalam program pembelajaran awal. Proses penilaian formatif yang tepat menyediakan data untuk menginformasikan instruksi kelas. Berbagai bentuk bukti yang menunjukkan perkembangan belajar siswa di berbagai bidang konten digunakan untuk mempersonalisasikan pembelajaran.

Checklist mencakup karakteristik kunci praktik asesmen formatif untuk mengamati partisipasi anak dalam kegiatan sehari-hari, peluang belajar dunia nyata yang terjadi dalam kegiatan, perilaku anak dalam peluang belajar sehari-hari, dan peluang belajar tertentu yang memberi anak serangkaian kompetensi terkaya dan meningkatkan peluang belajar. Indikator checklist dapat digunakan oleh seorang praktisi untuk mengembangkan rencana untuk melakukan asesmen anak yang otentik atau untuk mempromosikan pemahaman orangtua atau praktisi dan penggunaan pendekatan ini untuk penilaian/intervensi. Skala peringkat checklist dapat digunakan untuk evaluasi diri dan menentukan apakah karakteristik kunci digunakan sebagai bagian dari penilaian anak

\section{Portofolio}

Portofolio merupakan kumpulan karya anak yang dimaksudkan untuk menunjukkan kemajuan anak dari waktu ke waktu. Karya-karya ini merupakan sampel dari beberapa karya anak yang dapat diseleksi sendiri oleh anak maupun oleh anak dan guru yang menggambarkan pembelajaran terkait dengan tujuan instruksionalnya. Menurut (Zahrok, 2009) portofolio dapat memberikan gambaran terhadap kinerja dan pembelajaran anak, mengintegrasikan informasi dari berbagai sumber, dan menilai komitmen dan keterlibatan anak. Portofolio merupakan jenis penilaian yang relatif baru dalam pendidikan. Secara etimologi, portofolio bisa diartikan sebagai kumpulan (dokumen, berkas, bundel) bukti fisik tentang aktivitas. Pengumpulan data untuk asesmen portofolio terdiri dari mengidentifikasi informasi yang akan dimasukkan ke dalam portofolio, menentukan frekuensi pengumpulan data, membuat sistem untuk merekam dan memantau frekuensi pengumpulan data, dan menetapkan pedoman untuk menghilangkan dan memperbarui materi portofolio. Pedoman ini dapat bervariasi tergantung pada tujuan portofolio.

Portofolio telah banyak digunakan dalam pengajaran membaca dan menulis, dengan fokus yang kuat pada pengajaran di kelas, kepemilikan siswa dan evaluasi diri, dan otonomi guru. Menurut (Pierce, 2002) beberapa tahun terakhir, portofolio telah diusulkan dan diadopsi sebagai alat manajemen penilaian siswa di seluruh negara bagian di samping atau bukannya data tes prestasi belajar standar. Asalkan tujuan isi portofolio adalah untuk memperluas pemahaman tentang pertumbuhan siswa berdasarkan berbagai ukuran, berbagai jenis tes dan data non-tes dapat dimasukkan dalam portofolio.

\section{SIMPULAN}

Asesmen pada anak usia dini adalah tentang membuat rentang pembelajaran awal anak-anak terlihat. Ini dapat dicapai melalui proses pengumpulan informasi tentang pembelajaran anak-anak, mendokumentasikan informasi itu, merefleksikannya dan kemudian menggunakan informasi tersebut untuk mendukung dan memperluas pembelajaran. Kita juga telah melihat bahwa karakter dan kompleksitas pembelajaran awal mengharuskan penggunaan metode yang akan memungkinkan untuk pengembangan akun kaya awal pembelajaran awal anak-anak. Tampaknya pendekatan naratif adalah pendekatan yang menawarkan pendidik cara memberikan gambaran yang kaya tentang pembelajaran awal melalui mendokumentasikan contohcontoh pembelajaran tertentu; fokus untuk merefleksikan pembelajaran; alasan untuk membuat keputusan tentang ketentuan. Ini juga merupakan cara berkomunikasi dengan orang lain tentang pembelajaran anak-anak. Namun, kami juga telah melihat bahwa pendekatan naratif menantang untuk diterapkan dalam praktik.

Proses asesmen formatif adalah alat yang berharga bagi guru untuk mengamati dan berinteraksi dengan siswa mereka untuk belajar tentang perkembangan mereka setiap hari. Penilaian formatif mendorong guru untuk lebih sistematis dan konsisten dalam cara mereka memandang setiap anak dalam semua bidang pembelajaran dan pengembangan. Hal ini memungkinkan semua anak untuk menerima instruksi individual yang mereka layak dapatkan, khususnya memungkinkan anak-anak berprestasi untuk melangkah lebih jauh, anak-anak yang berprestasi lebih rendah untuk menerima dukungan yang mereka butuhkan, anak-anak yang pendiam untuk didengar, dan mereka yang berperilaku menantang menjadi dipahami di luar perilaku. Penilaian formatif juga menggarisbawahi ranah kognitif yang sering diabaikan, seperti sains atau geometri. Ini memberikan perhatian dan pertimbangan pendekatan untuk belajar dan perkembangan sosial dan emosional anak-anak. Penilaian formatif mendukung pendidik agar lebih responsif terhadap kebutuhan dan minat perkembangan anak kecil. 


\section{DAFTAR RUJUKAN}

Ayers, S. R. (2014). Formative Assessment : Guidance for Early Childhood.

Bodrova, E., \& Leong, D. J. (1996). Tools of the mind: The Vygotsky Approach to Early Childhood Education. Engelwood Cliffs. Prentice-Hall, Inc.

Bredekamp, S., \& Rosegrant, T. (1992). Guidelines for Appropriate Curriculum Content and Assessment. National Association for The Education of Young Children, 1(2), 9-27.

Carr, M. (2001). Asessment in Early Childhood Settings. SAGE.

Clark, P., \& Kirk, E. (2000). All Day Kindergarten. Childhood Education Summer, 76(4), 228-231.

Dunphy, E. (2010). Assessing early learning through formative assessment: Key issues and considerations. Irish Educational Studies, 29(1), 41-56. https://doi.org/10.1080/03323310903522685

Frisby, R. (2001). User Involvement in Mental Health Branch Education: Client Review Presentations. Nurse Education Today, 21(8), 663-669.

Hus, V., \& Matjašič, J. (2017). Evaluation and Assessment in Early Social Science. 5(4), 664-670. https://doi.org/10.13189/ujer.2017.050415

Irayana, I. (2017). Pengembangan Screening Asessment untuk Meningkatkan Kompetensi Guru dalam Mengidentifikasi Perkembangan Bahasa Anak Usia Dini. Indonesian Journal of Islamic Early Childhood Education, 2(1), 99-108.

Novianti, R., Puspitasari, E., \& Chairilsyah, D. (2013). Pemetaan Kemampuan Guru PAUD dalam Melaksanakan Asesmen Perkembangan Anak Usia Dini di Kota Pekanbaru. SOROT, 8(1), 95-104.

Piaget, J., \& Inhelder, B. (1997). The Child's Construction of Quantities: Conservation and Atomism (Vol. 2). Psychology Press.

Pierce, L. V. (2002). Performance-Based Assessment: Promoting Achievement for English Language Learners. ERIC/ Applied Linguistics, 26 no. 1, 3-5.

Santrock, J. W. (2009). Psikologi Pendidikan (3rd ed.). Jakarta: Salemba Humanika.

Sarivan, L. (2011). The Reflective Teacher. Procedia - Social and Behavioral Sciences, 11, 195-199. https://doi.org/10.1016/j.sbspro.2011.01.060

Setiawan, H., Sa'dijah, C., \& Akbar, S. (2017). Pengembangan Instrumen Asesmen Autentik Kompetensi pada Ranah Keterampilan untuk Pembelajaran Tematik di Sekolah Dasar. Jurnal Pendidikan: Teori, Penelitian, dan Pengembangan, 2(7,) 874-882.

Sukmadinata. (2013). Metode Penelitian Pendidikan. Bandung: Remaja Rosdakarya.

Wiggins, G. (1998). Educative Assessment. Designing Assessments to Inform and Improve Student Performance. ERIC.

Zahrok, S. (2009). Asesmen Autentik dalam Pembelajaran Bahasa. Jurnal Sosial Humaniora, 2(2), 166-180. 